\title{
Acculturation Chinese Symbol on Madura Batik Motif
}

\author{
Ong Mia Farao Karsono ${ }^{1} \&$ Lintu Tulistyantoro ${ }^{2}$ \\ ${ }^{1}$ School of Chinese Literature, Petra Christian University, Indonesia \\ ${ }^{2}$ School of Interior Design, Petra Christian University, Indonesia \\ Correspondence: Ong Mia Farao Karsono, School of Chinese Literature, Petra Christian University, \\ Siwalankerto 121-131, Surabaya, Indonesia. E-mail: ongmia@gmail.com
}

Received: November 13, 2015 Accepted: March 9, 2016 Online Published: March 23, 2016

doi:10.5539/ass.v12n4p200 URL: http://dx.doi.org/10.5539/ass.v12n4p200

\begin{abstract}
This study has two chief purposes. Firstly, to introduce the Madurese Batik from Indonesia which has not yet been widely studied, and secondly, to show the acculturation of the Chinese culture in the motif of Madurese Batik. Research method employed in this study was descriptive qualitative, because our topic involves cultural and humanity sciences. The writers interview batik makers from the towns of Pamekasan, Tanjung Bumi, Sumenep, and Sampang, as research informants. We take two batik makers as representatives of each town. The four towns are selected because those towns are the centers of batik in Madura. To crosscheck the information obtained from the batik makers, also interview two collectors of Madurese batik who have good knowledge of Madurese batik. The data from the interviews and the photographic documentation of Madurese batiks are sorted and then analyzed by relating them to the theories about Madurese culture, acculturation process, and Chinese culture. The discussions and conclusions of the analyses correspond with the hypotheses proposed at the beginning of the study, which states that there are acculturations of the symbols on Madurese Batik motifs, which can be seen in the paintings of phoenix, butterfly, fish, bamboo trees on the batik, and that the acculturation process occurs naturally without conscious knowledge of the Madurese.
\end{abstract}

Keywords: acculturation, Madurese batik, motif, Chinese culture symbols

\section{Introduction}

Batik is a very valuable cultural product of Indonesia. All the more, in 2009 the United Nations has decreed that Indonesian batik is a cultural heritage which should be preserved. The UNESCO (United Nations Educational, Scientific and Cultural Organization) has included batik in world cultural heritage. The decree is really significant for Indonesian nationalists. The Indonesian Government has worked hard to gain this acknowledgement, and has struggled to protect batik from motif thefts by other nations. At present the government has also obtained the copyrights of 300 Indonesian batik designs. Most of these copyrights were obtained after 2007. Thus, it is quite appropriate for us as Indonesian citizens to study Madurese batik motifs and present the study in international journals with the hope of introducing Madurese batik motifs to more people.

Why do we study the acculturation of Chinese culture in Madurese batik? The answer is because both Indonesia and China have batik crafts and both crafts have a long history. The Overseas Chinese Affairs Office of the State Council (2007) states that Chinese motif cloth printing and batik is a traditional technology product of the Chinese people. Chinese art craft has a very long history (p. $204 \&$ 186). Gǔ (2014) also states that Chinese batik craft has existed in China since the time of Xià 夏 dynasty (21 BC-16 BC), Shāng 商 dynasty (16 BC-11 BC), and Zhōu 周 dynasty (11 BC-221 AD), and reaches its peak in the Táng 唐 dynasty. During the Sòng 宋 dynasty, batik making in China dropped greatly because of the long time it took for the coloring process and the color produced was mono color. Batik making still survives in southwest and central China which is the dwelling place of ethnic minorities in China (pp. 1-3). The ethnic minorities have high skills in handycrafts including batik making (Hán, 2002, p. 32). From this background we make the hypothesis that the motif of Chinese batik significantly influences the motif of Indonesian batik.

Concerning the history of Indonesian batik, Batik Market (2015) reports that batik has been known in Indonesia since the seventeenth century, when batik was painted on palm leaves. The batik motif at that time were mostly paintings of animals and plants. On further developments, abstract motifs were added such as cloud motif, temple reliefs, Javanese puppets, and so on. Then, by combining the painting style with cloth decorating, 
emerged the hand painted batik that is known today. The motif of hand painted batik usually contains the philosophy of each region from where the batik comes. Formerly batik was only made within the palace community and was worn only by the royal family and the court people. Because many of the court people lived outside the palace, they brought batik art out of the palace and then they also made batik in their own places. Today, batik is worn by the public (http://www.batikmarkets.com/cara_membuat_batik.php).

The term "batik" comes from the word "hamba-tik" which means 'titik'. This titik motif is the oldest batik motif (Samsi, 2011, p. 3). The tools needed in batik painting are mori cloth (made of silk, cotton, or polyester mix); pencil (for drawing the design); canting made of metal (bronze, brass, or zinc) with a mouth (which is used for scooping hot melted wax); wax for covering the painting on the cloth; dye; a pan; a small stove for heating the wax; gawangan (for hanging the cloth). The procedure of making hand painted batik as outlined by Batik Market (2015) includes three steps. The first step is drawing the design of the motif on mori cloth with a pencil. The second step is using canting which has been filled with hot melted wax to cover the design. When the wax has dried, the cloth is dipped into a dye solution, the part of the cloth which has been covered by the wax will not be affected by the dye solution. The third step is nglorot, in which the cloth which has changed color is boiled to take off the wax from the cloth so that the motif which has been drawn on the cloth is seen more clearly. The dipping in a dye solution will not change the color of the part of the cloth where the motif is drawn since it is covered by a thin layer of wax (the wax does not wear off entirely). A batik that is made by this process is called hand painted batik. Besides hand painted batik there is also printed batik. Both hand painted batik dan printed batik use hot melted wax. The difference lies in the way of putting the wax on the cloth: in printed batik the wax was stamped on the cloth, while in hand painted batik the wax was drawn on the cloth using canting. (Batik Market, Tuesday, April 14, 2015 http://www.batikmarkets.com/cara_membuat_batik.php).

The hypothesis that there has been an acculturation of Chinese culture in the motif of Madurese batik in the form of religious symbols is based on the fact that Chinese culture has entered Indonesia since year 1172, especially during the reign of King Sriwijaya. This is confirmed by Kǒng (1999) who stated that in year 1172 King Sriwijaya ordered roof tiles from the government of the Song 宋 dynasty (p. 349). Then the entrance of Chinese immigrants to Indonesia several centuries ago has also made a great impact. These Chinese immigrants bring forth the peranakan (descendant) culture which is the fusion of two cultures namely the Chinese culture and the local culture to form a new culture which is called peranakan (descendant) culture. This descendant culture has reached all realms in Indonesian community, among others, fashion (kebaya/Javanese blouse, batik, shoes, and so on), culinary (soto, kecap, kue tok, lumpia, and so on), daily expressions and daily habits. If we trace back the descendant culture, we see clearly that the culture has developed within the community of the descendants of the Chinese immigrants and is different from the original foreign culture and also from the local culture. Thus the cultural acculturation in batik motif is an interesting topic to be studied.

We select Madurese batik as our research topic because in comparison to the Javanese communities in general, the Madurese are known to have a unique culture and character. The acculturation in their culture has occured since the sixteenth century as can be seen in the variety of keris (Javanese traditional knife) decorations, ladies' jewelry such as bracelet, binggel/gold ring worn around the ankle, pending/pin, and so on; daily utensils (cooking pan, ladle, tray, and so on); stone carving (tomb stone, statue, roof decoration); wood carving (bed, ship decoration, furniture) (Sunaryo, 2009). Wiryoprawiro (1986) states that Madura has a comparably large number of Chinese citizens, which was officially recorded in history in the eighteenth century after the Pecinan riot in Surakarta, when a large group of Chinese people arrived in Madura from Java. One of them was Lauw Koen Thing family who were skilled in construction building. Later they were trusted by the local dignitaries to perform works according to their skill. The results among others were the building of Sumenep Palace (1764) and Sumenep Grand Mosque (1781), which was built by Lauw Pia Ngo, the grandson of Lauw Koen Thing (pp. 32-35).

The urgency of this study lies on the fact that there are still very few studies on Madurese batik. The more popular topics of batik studies are about batik from the towns of Central Java, such as Yogyakarta, Solo, Cirebon, and so on. Besides, there has been a study on the acculturation of Javanese culture, European culture, and Chinese culture on Madurese community, performed by Tulistyantoro (2009). These backgrounds encourage us to make a study on the Madurese batik, especially the acculturation of Chinese culture in the motif of Madurese batik. It has been widely known that China is rich with symbols with high philosophical values.

As presented by Setyorini et al. (2013), batik-making business has given a considerable contribution to medium business trade. Thus, studies on batik are worthy to be developed more widely. Moreover, at present we have the Association of Central Java batik and Southern Java batik such as Yayasan Batik Indonesia (Indonesian Batik Foundation) which promotes national and global batik-making business. Indonesian Batik-Making Business 
needs to be revitalized in order to accomodate the raw materials from certain regions (p. 22, 28). Our study proposes two formulations of problem, namely: (1) How the Chinese culture influences the motif of the batik made in Madura, (2) What factors show that the acculturation of Chinese culture in the motif of Madurese batik is worth studying.

\section{Material Studied}

To support the data analysis process we use the theories about the situation of the Madurese community; the meaning of cultural acculturation; the Chinese symbols which have philosophical values. The symbols include the Figures of dragon which symbolizes grandeur; phoenix which symbolizes beauty (Williams, 1993, pp. 132-134); heron which symbolizes a vehicle to heaven (Williams, 1993, p. 101); butterfly which symbolizes the happiness of husband and wife (Ong, 1993, pp. 262-263); fish which symbolizes continuous prosperity (Ong, 1993, p. 244), fan which symbolizes elegance. It is quite interesting to study the motifs of Madurese batik which embody those Chinese symbols.

\section{Research Method}

This study uses the qualitative approach and descriptive analysis, because it studies the phenomena of human culture acculturation which belongs to the scope of social science. A qualitative study needs interactions between the researcher and the selected informants so that the informants will feel at ease in answering the questions asked during the interviews. This approach is similar to the one used by Karsono (2014, p. 300) which is presented in the journal article titled "The Downfall of Chinese Family Business in East Java, Indonesia", namely by building a good relationship with the informants before making interviews. We select makers of Madurese batik from four towns, namely Pamekasan, Tanjung Bumi, Sumenep, and Sampang, because those towns are the centers of Madurese batik. To ascertain the accuracy of the data obtained from the batik makers, we also interview two batik collectors who have extensive knowledge of the character of Madurese batik.

The interviews are recorded and the data obtained is put into text consisting of questions and answers which function as raw data. This raw data is sorted and then we select the data that can be used to solve the formulations of problem and put that data in a separate file. Our next step is to analyze the selected data by relating it to the theories that have been proposed previously. We analyze the data by giving it interpretation which relates to the theories proposed earlier in a similar way as the analysis in the journal of Karsono (2014, pp. 9-10) titled "Chinese Language an Identity Viewed by the Younger Chinese Ethnic in Indonesia".

\section{Result and Discussion}

The results obtained confirm the hypothesis stated earlier which proposes that there is an acculturation of the symbols of Chinese culture on Madurese batik of the towns of Pamekasan, Tanjung Bumi, Sumenep, and Sampang.

\subsection{The Acculturation of the Symbols of the Chinese Culture on Pamekasan Batik}

The town of Pamekasan lies about $120 \mathrm{~km}$ from the capital of East Java. From surveys and interviews to two batik makers we find that batik with dragon motif is made when there is an order for it. This indicates that the community in the town is open to other cultures especially the Chinese culture. Figure 1 shows Pamekasan batik with dragon motif in the shop of an informant. This batik is ordered by customers from Surabaya and Jakarta. The Chinese motif becomes significant because dragon is not common for the Madurese, however economic value causes this acculturation to occur smoothly.

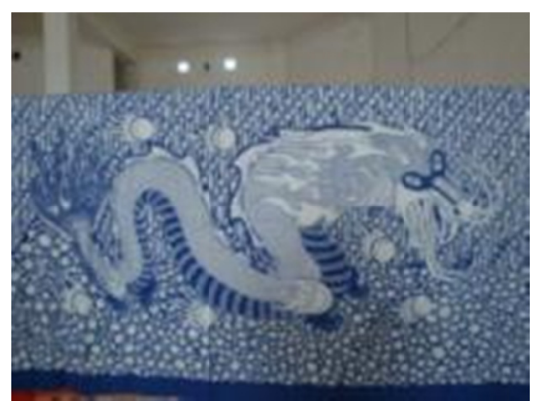

Figure 1. Modern Pamekasan batik with dragon motif (Karsono, 2015, p. 4)

We also find a Pamekasan batik with fan motif. Our first informant says the fan motif symbolizes a holy leader. 
In China, fan symbolizes cleverness and dignity (Yáo, 2013), thus both Indonesians and Chinese acknowledge fan as a symbol of good things. While reng-pereng (bamboo) symbolizes a person's ability to live diligently and to face life's problems. This also fits the Chinese philosophy. The Chinese like the bamboo tree because it can live in any season. Figure 2 is a photograph document of Pamekasan batiks with the symbols of fan and bamboo tree.

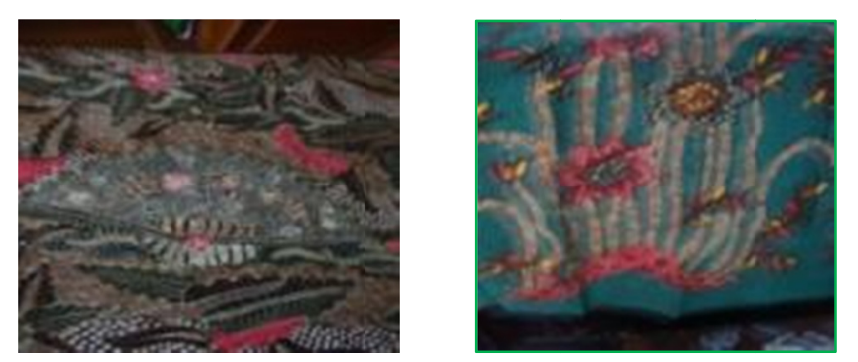

Figure 2. Pamekasan Batik with fan and reng-pereng (bamboo) motifs

Nowadays most batik makers do not think of philosophy when they design their batik. Only in batik-making competitions they include the philosophical aspects in their batik. The motifs of Pamekasan batik are made spontaneously according to the creativity of the painter or according to the wish of the customer. The batik makers only think about the philosophy of their batik when they participate in batik-making competitions, either locally, regionally, or nationally.

The other motifs which are often found in Pamekasan batik are bird, per-keper (butterfly), large chrysanthemum, and small sakura flowers. The Pamekasan batik makers have the the habit of not drawing the real animals but they draw the animals vaguely, for example when they draw butterflies, they only draw the outlines or they draw the butterflies without eyes. Their elephant motifs are usually not large and sometimes the heads are in the form of flowers. The fish motifs are drawn with line and dot isen (inside fill in batik which is generally used as background). Figure 3 shows the photographs of the motifs of Pamekasan batik with various bird paintings which we take from batik makers in Pamekasan while we are making observations and interviews. The motif of living creatures are not similar to the real ones because of the prohibition to draw a living creature on a batik cloth. Therefore, the painting of living creatures in batik are not the same as the real ones.

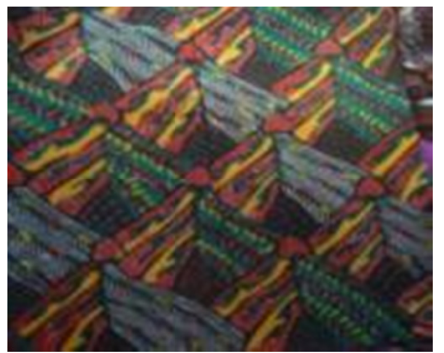

Pamekasan batik with "the Dawn" motif, the peacock is drawn vaguely

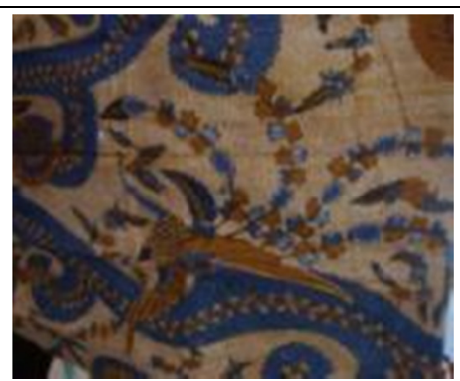

Pamekasan batik with "Phoenix" motif, the tail has a few feathers

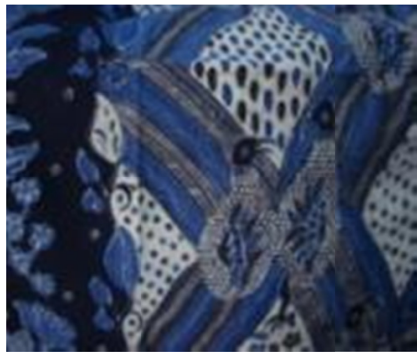

Pamekasan batik with "the Dawn" motif and the drawing of a pair of peacocks

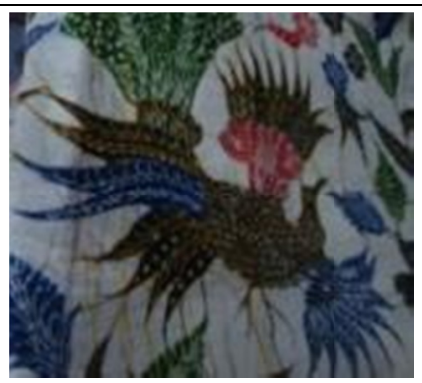

Batik Tanjung Bumi with peacock motif, the tail is gathered

Figure 3. Pamekasan and Tanjung Bumi classical batik with various bird motifs (Karsono, 2015, pp. 8-10) 
The pair of birds motif in Pamekasan batik as shown in Figure 3 is called Fajar Menyingsing (the dawn) which is a classical batik. This motif is similar to the batik from other places such as Sidoarjo and Indramayu. Being a classical batik, it has the philosophy of joy in the morning or the zeal for life. In Figure 3, if the bird's tail has a few feathers, then the motif is called "Phoenix". If the bird's tail is not spread, the the motif is called "Peacock" or just "Bird". This shows that there is an acculturation of Chinese culture in Madurese batik. Besides bird motif, in Pamekasan batik we also find Liris (Lines) motif, Bem-ombek (Waves) motif, and Okel (Curves) motif.

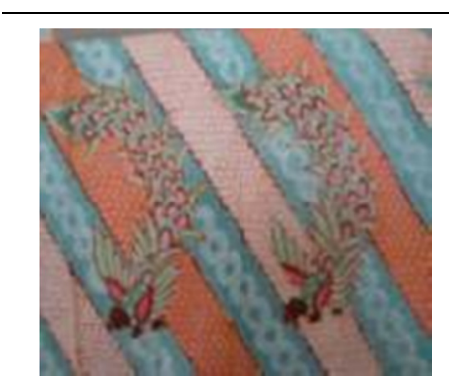

Pamekasan batik with "Liris" (Lines) motif

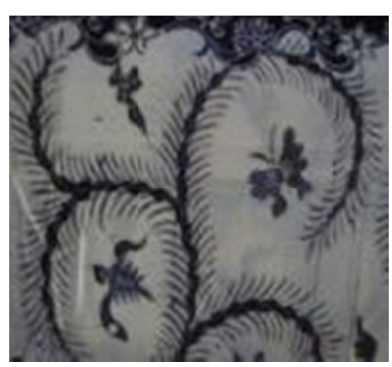

Pamekasan batik with "Okel "(Curves) motif

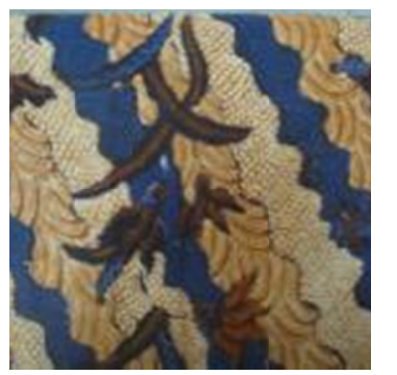

Pamekasan batik with "Bek-ombek" (Waves) motif

Figure 4. Pamekasan batik with various motifs

From Figure 4 we find that batik is named according to its main pattern. In the Pamekasan batik with Liris (Lines) motif we also see the drawing of birds. There are also drawings of birds in Pamekasan batik with Bek-ombek (Waves) motif. While in Pamekasan batik with Okel (Curves) motif we can find drawings of birds, butterflies, and fish. The basic motifs in Madura and Pamekasan batik often represent plants, birds, or butterflies. The butterfly motif is even used for special occasions, for example the Per-Keper motif, which means a pair of butterflies, is used in the marriage ceremony. The similarity in motif and in ceremonial use indicates a very close cultural acculturation. The Chinese culture is well acquainted with the symbol of butterfly which signifies true love between a pair of lovers, and which is popularly known through the "Sampek Ingtai" legend. The Per-Keper (a pair of butterflies) motif in Pamekasan batik also has the same philosophy, it symbolizes true love between a couple. Figure 5 shows the photographs of the batik.

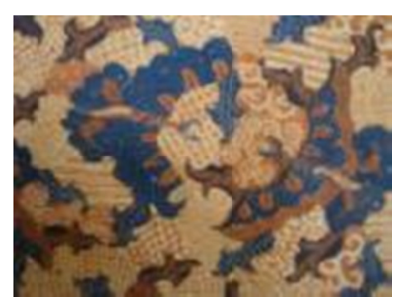

Classical Pamekasan batik "Per-Keper" (a pair of butterflies) motif

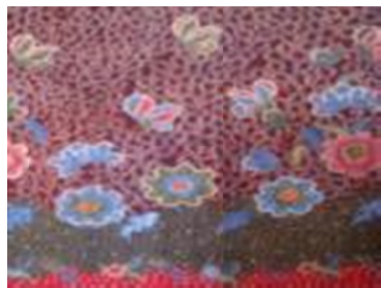

Modern Pamekasan batik with vaguely drawn butterfly motif as decoration

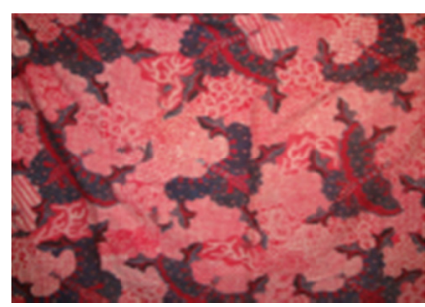

Pamekasan batik "Per-Keper" (a pair of butterflies) motif in a modern coloring

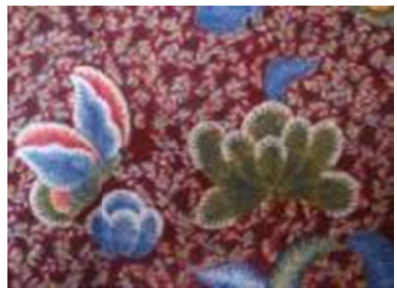

Modern Pamekasan batik with butterfly motif as decoration

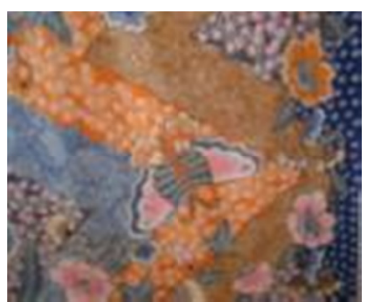

Modern Pamekasan batik "Butterfly" motif as decoration

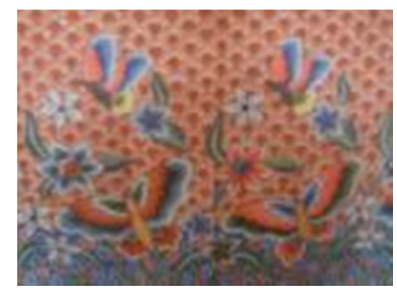

Modern Pamekasan batik with butterfly and flower motif as decoration

Figure 5. Pamekasan batik with various butterfly motifs 
The common floral motif in Madura is the flower motif. The main motif in the form of bouquet, which in local language is usually called buketan, is also common here. The Madurese also call the flower motif "kembhang" which means flower with a lot of variations. Figure 6 shows modern Pamekasan batik with various flower forms.

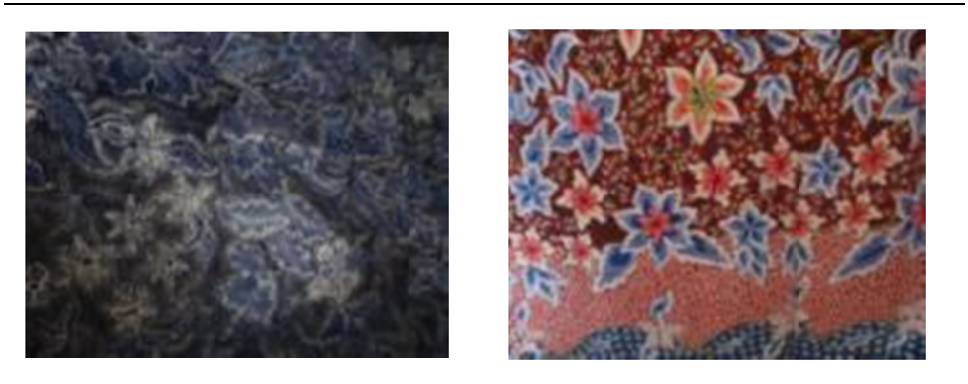

Figure 6. Pamekasan batik with flower motif

The modern Pamekasan batik are usually of bright/strong colors such as red, blue, orange, pink, green, yellow, black. Figure 7 shows the photographs of Pamekasan batik with its color.

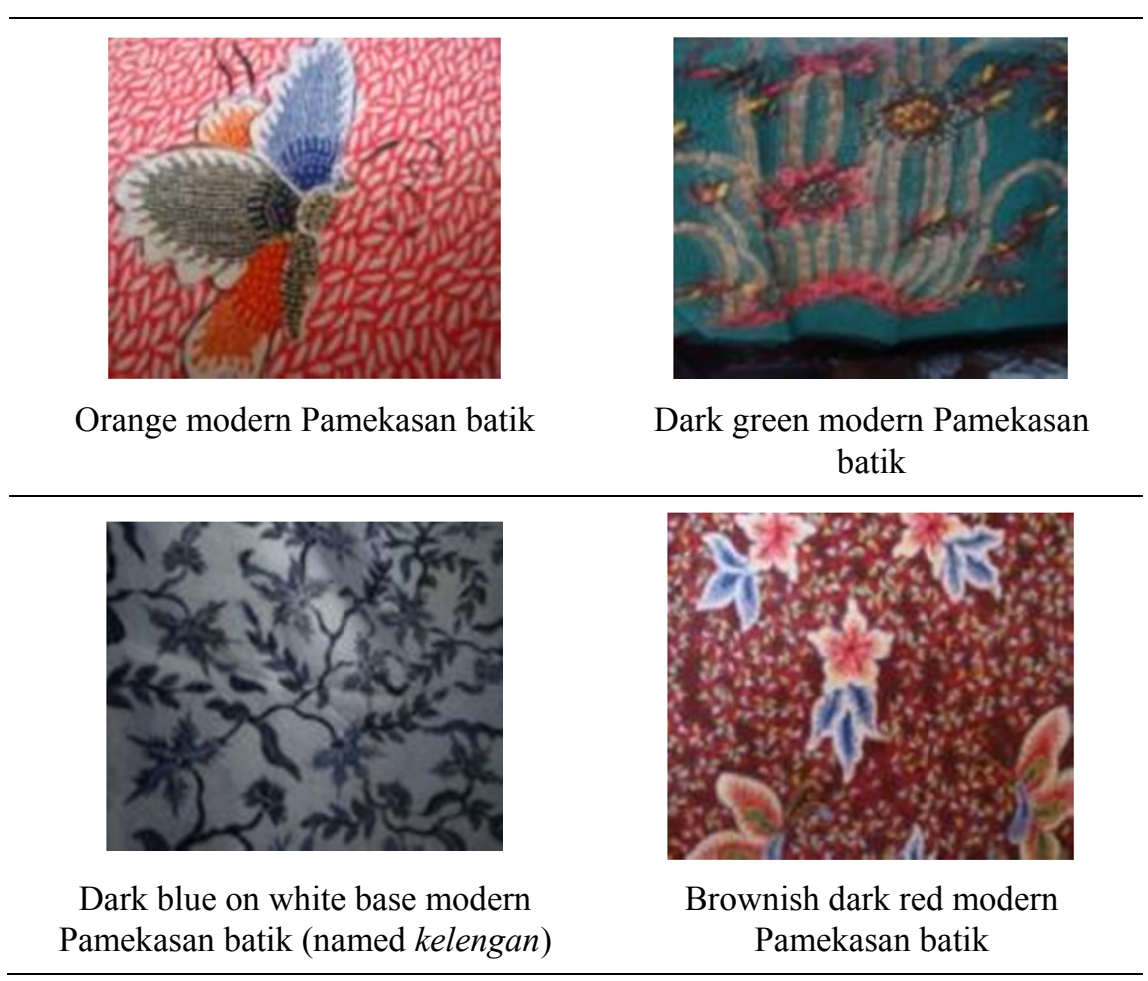

Figure 7. Modern Pamekasan batik with various colors

The main elements of batik are motif, pattern, and main motif. Isen is the inside fill in batik which is generally used as background. Pattern is the structure of the drawing, while the main motif is the most dominant motif in a batik cloth. Concerning isen characteristic, from the interviews with informant (1) and (2) we find that the commonly used isens are cecek (dot), rawan (lines), spilled rice, half moon, okel (curves), bang gedung, kobhung, chicken feathers, and so on. Thus we can conclude that the theme of the isen of Pamekasan batik is usually taken from plants or nature around them. The type and the elegance of the isen determines the quality of a batik. In Figure 8 we can see the examples of $i s e n$. 


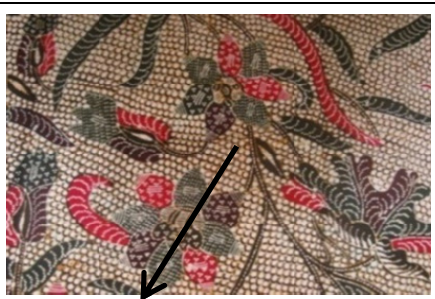

Gringseng isen of classical Pamekasan batik

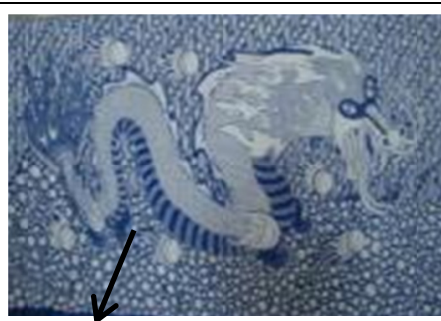

Circular isen of modern Pamekasan batik

Figure 8. The isens of Pamekasan batik

Pattern includes among others liris, bek ombek, kobhung, kar jagad, and so on. While main motif includes among others pring sedapur, buketan, tong centong, per keper, and so on. Sometimes batik motif is based on the imagination of the batik maker. If one batik cloth has several isens, the batik will be named according to the most dominant isen. Certain isens such as Sekar Jagad motif is common in Java, which symbolizes world map. The word kart comes from Dutch which means map, while jagad comes from Javanese which means the world, including Indonesia and all the world. Sekar Jagad motif means variety, both in Indonesia and in all the world. This motif also means beauty which fascinates anyone who sees it (Wolody \& Chian, 2004, p. 80). Sekar Jagad motif which implies variety is represented in repeated geometrical form which is drawn alone or in pairs side by side. It symbolizes the beauty and the greatness of the life in the world. The appearance of Sekar Jagad batik is usually flowery with color variation in each section. This motif started to develop in the eighteenth century and still survives until the present time because it is beautiful and attractive. Batik with Sekar Jagad motif is generally used in the marriage ceremony of young couples, which signifies their true love to each other (Wolody \& Chian, 2004, p. 80) (Figure 9).

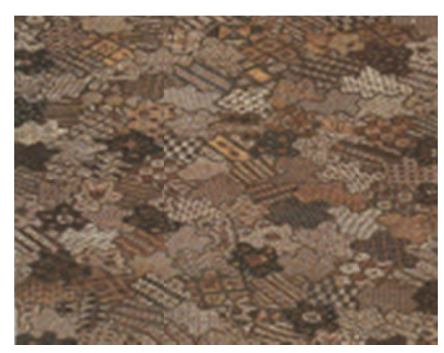

Figure 9. Pamekasan batik with Sekar Jagad $d$ motif

In order to comply with market requirements of customers who do not like the motifs of classical batik, batik makers in Pamekasan also produce batik with contemporary motifs. In contemporary motifs the flower and animal motifs are changed into garis bangun motif as seen in Figure 10, while the colors are usually bright.
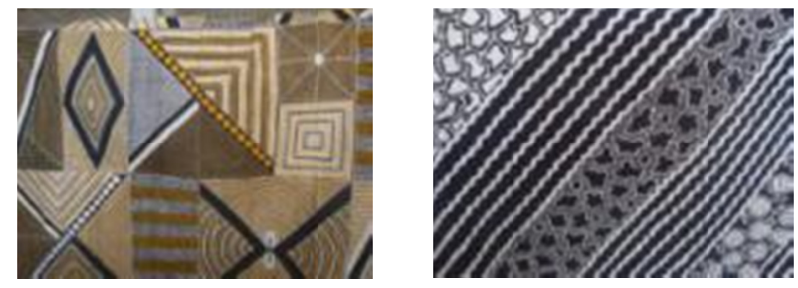

Figure 10. Pamekasan batik with contemporary motifs

There are also modern motifs with fish drawing in Pamekasan batik. Fish drawing symbolizes prosperity among the Chinese people (Ong, 1993, p. 244). Fish drawing is also popular and used as batik motif in Pamekasan, which indicates that there has been natural acculturation which occurs without the conscious knowledge of the Madurese. 


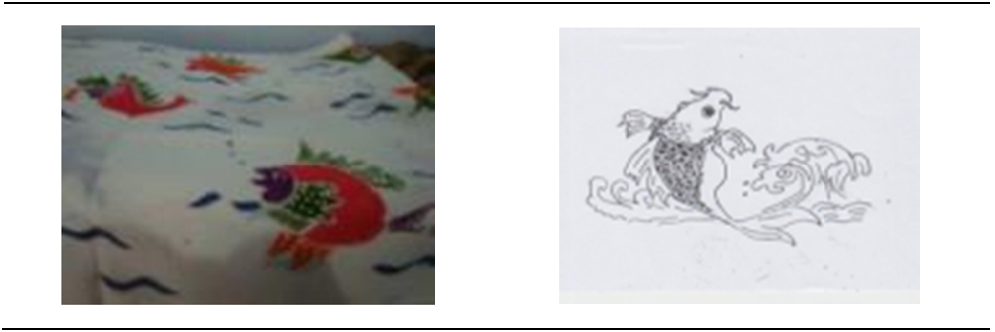

Figure 11. The fish motif in local batik and in Chinese symbol

There is a difference between the fish motif of modern Pamekasan batik and the fish motif which symbolizes prosperity in the Chinese culture. The fish motif in Madurese batik is painted horizontally, while in Chinese painting the fish is drawn jumping upward. The Chinese symbol is painted upward to represent increasing prosperity. Besides fish, there is also heron in the motif of Madurese batik, which symbolizes a long life. If we look carefully, we will see that one of the heron's leg is lifted which in the Chinese culture is the symbol of a vehicle to western heaven for the soul of a dead person (Williams, 1993, pp. 101-102). Figure 12 shows the heron painted according to Chinese philosophy, with one leg lifted. The heron in Pamekasan batik is always painted with one leg lifted, too. Thus the Madurese paint the heron according to the Chinese painting.
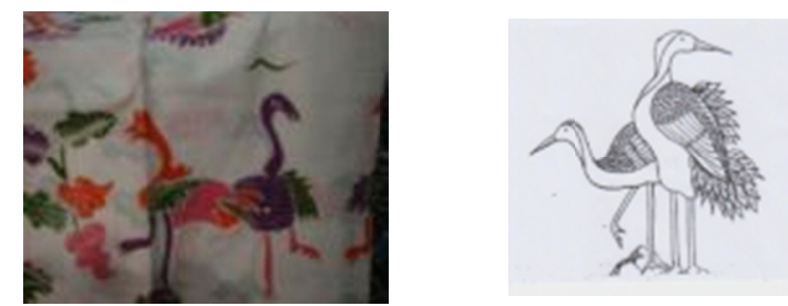

Figure 12. The similarity between the Chinese symbol of the heron and the modern Pamekasan batik with heron motif

Although from the interviews with the research informants we find that they make batik without thinking of the philosophy of the batik, classical Pamekasan batik motifs generally have philosophical meanings, such as Sekar Jagad motif and Reng-Pereng motif. There are also other classical motifs such as Sabet Manik or Sabet Rantai, Per Keper, Melate Seto'or and Tong Centong. These motifs are only used in the marriage ceremony, as the present from the bridegroom to the bride, because they have the philosophical meaning about the bridegroom's love and ability to take care of the bride in the future. Sabet Manik symbolizes the promise which binds the love between the bridegroom and the bride, Per-Keper symbolizes the strength of love which can not stopped by death, Melate Seto'or symbolizes the true love of the couple. Tong-Centong symbolizes prosperous life with abundant food because centong or entong is a kind of ladle used for taking cooked rice from the cooking pan. In Figure 13 we can see the photographs of Pamekasan batik with Sabet Manik, Tong Centong, Melate Seto'or motifs.
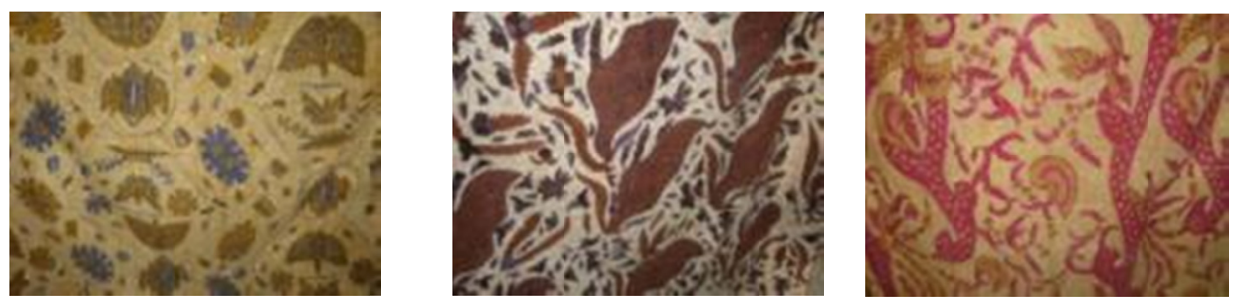

Figure 13. Classical Pamekasan batik with Sabet Manik, Tong Centong, and Melate Seto'or motifs

Thus, there has been an acculturation from Chinese culture in Pamekasan batik, both in color and motif, which can be seen from the large number of bird, butterfly, and dragon motifs. In the coloring of modern batik, the Madurese in Pamekasan are quite flexible, they can suit their customer's wish. If the customer wants red color, 
they will make batik with a red color, and in fact there are many Pamekasan batiks with bright red color. Red is also the favorit color of the Chinese because it symbolizes prosperity and power, and it drives away calamity. According to legend, in ancient China lived a strange animal which liked to scare the village people. However, if the doors and windows of a house were covered with red paper, the strange animal did not dare to enter the house, and then it would leave the village. Since then the Chinese believe that red color can bring prosperity and drive away calamity. Besides, they also believe that red color symbolizes power and courage (Wáng, 2012).

\subsection{The Acculturation of the Chinese Culture on Tanjung Bumi Batik}

The town of Tanjung Bumi lies about $50 \mathrm{~km}$ from the town of Bangkalan in Madura. The interview with our research informant (4) shows that Tanjung Bumi is a coastal town whose people are mostly fishermen, and when the husbands go to sea to catch fish, the wives have time to make batik. This agrees with the statement in the book released by the Minister of Tourism and Creative Economy of the Republic of Indonesia (2009), which says that batik makers are generally ladies, both married and young ones (p. 41). Nowadays it is difficult to find someone who is willing to paint batik on both sides of the cloth, the inside and the outside. It is also difficult to find someone who is willing to make batik with an unknown or new motif. Tanjung Bumi is a coastal town and its men are mostly fishermen, however the batik motifs of the town are mostly painting of birds, not of fish, crab, or other sea creatures. When we ask a research informant about this, he can not tell the reason. Figure 14 shows the photographs of Tanjung Bumi batik with bird motifs which we take when we are visiting two batik makers in the town.

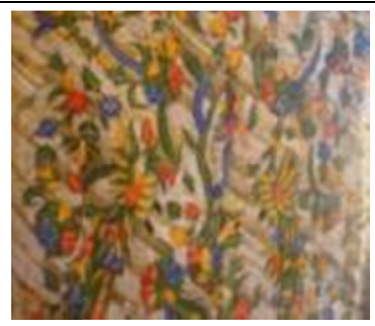

Peacock with long tail motif

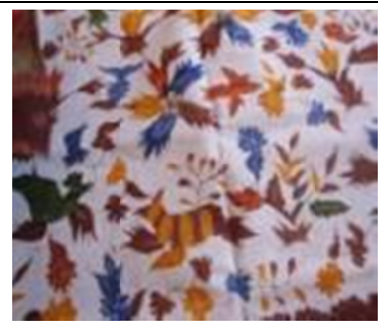

Fish and Bird motif which is a characteristic of Tanjung Bumi batik.

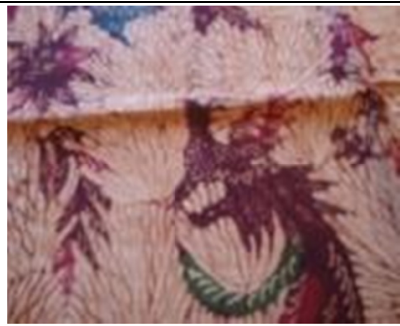

Phoenix classical batik motif with ramuk akar isen

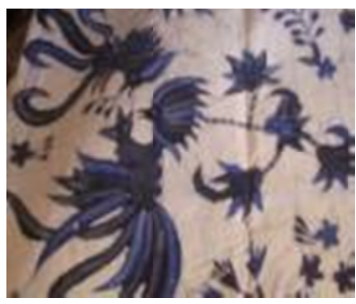

Phoenix classical motif

Fish and Bird classical motif

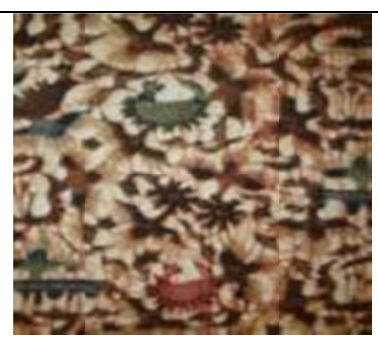

Bird motif
Bird classical motif with ge-toge isen
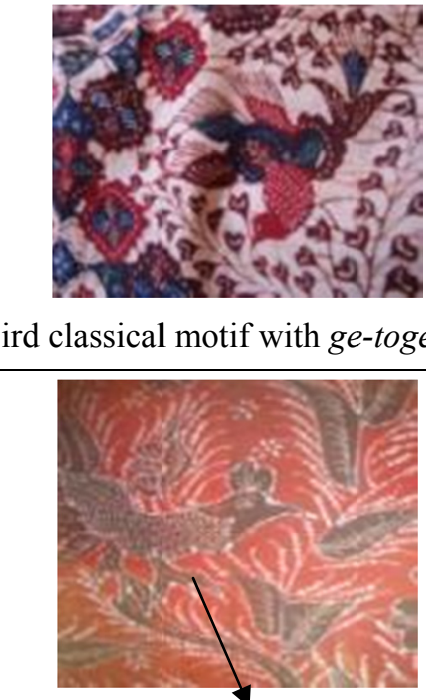

Bird motif with Kembang Gadung isen

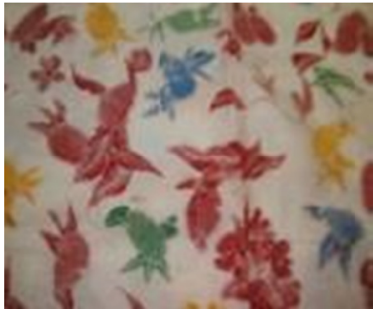

Bird motif

Figure 14. The photographs of Tanjung Bumi batik with various Bird motifs

Concerning the bird motifs in Madurese batik, whether from Pamekasan, Tanjung Bumi, Sumenep, or Sampang, if the bird's tail does not spread, then it is a peacock; if the bird's tail spreads, then it is a phoenix from China. Although Tanjung Bumi batiks are mostly of bird motifs, there are also batiks with butterfly and modified elephant motifs, as shown in Figure 15 and 16. 


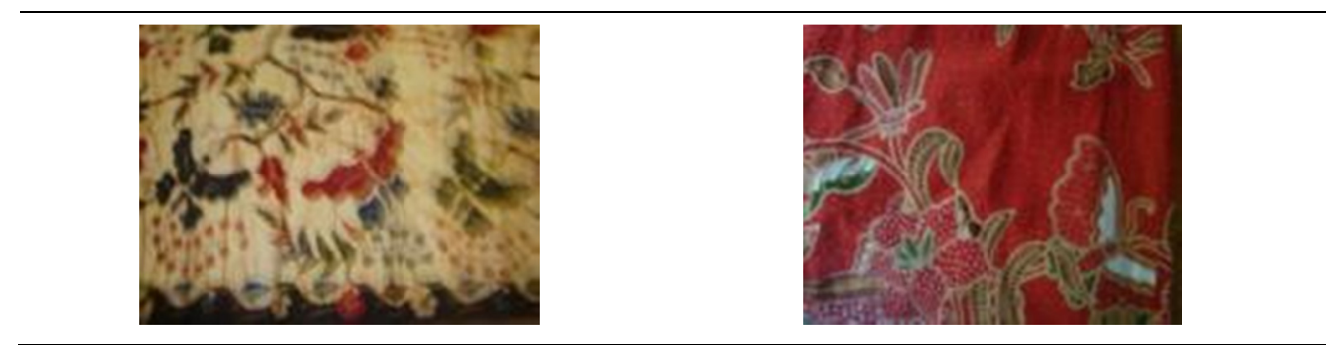

Figure 15. Tanjung Bumi batik with butterfly motif

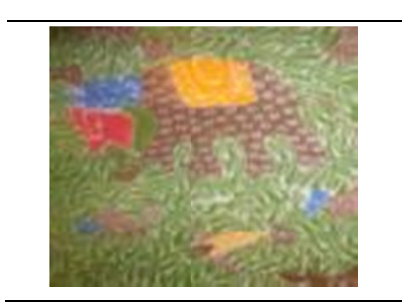

Figure 16. Tanjung Bumi batik with contemporary elephant motif

As in Pamekasan batik, in Tanjung Bumi there are also batiks with heron and chicken motifs. The heron here also lifts one leg. This shows that there has been an acculturation of Chinese culture on Tanjung Bumi batik. Our research informants can not tell the reason why the heron does not stand on its two legs, but lifts one leg as in the Chinese philosophy. Figure 17 gives the photographs of the batik with heron and chicken motifs.

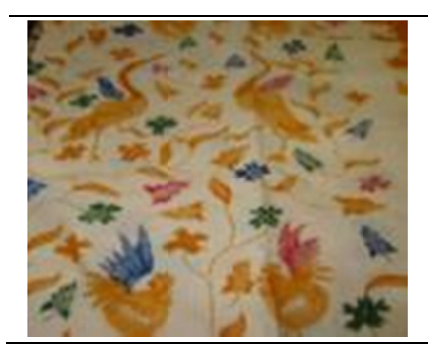

Figure 17. Tanjung Bumi batik with heron and chicken motif

The differences and similarities of Pamekasan batik and Tanjung Bumi batik have been studied by Fadilah (2010). Fadilah states that both Pamekasan batik and Tanjung Bumi batik use plant and animal motifs, while the difference lay in the fact that in Tanjung Bumi batik the motif was stronger and the color was thicker. The motif of Pamekasan batik was not so intricate as the motif of Tanjung Bumi batik. A more specific cause was given by the subject of our study (9) who says that the motif and color of Tanjung Bumi batik is different because it is consistent in color, while Pamekasan batik has been impregnated by elements from outside its region so that its color is more varied and its motif does not follow the strict rule as Tanjung Bumi batik.

In the isen of Tanjung Bumi batik there is a swastika or banji motif which is derived from Chinese motif. Figure 18 shows the photograph of this batik.

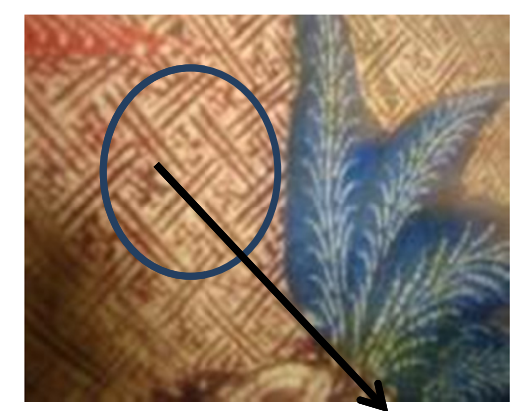

Figure 18. Tanjung Bumi batik with Panji (Swastika) motif 
The Madurese call the Swastika () symbol Panji. This symbol is known by many people, including the Chinese, as the symbol of luck, while the German used it as the symbol of Nazi, which gives it a dark (negative) connotation, while in reality it is not so. According to Prasetyo (2014) the swastika symbol in Sanskrit has a very different meaning from what is understood today. In Sanskrit the swastika means prosperity. This symbol has been used by Hinduist, Buddhhist, and Yudaism since ancient times. When Europeans migrated to Asia, they associated the symbol with positive thoughts and wise traditional values. In the beginning of the twentieth century many Westerners considered swastika as the symbol of luck.

Besides classical batik with Panji motif, there are also classical Tanjung Bumi batiks with the painting of jasmine flowers called Bhang Melate which symbolizes the pure love between husband and wife. Figure 19 shows the photograph of this batik.

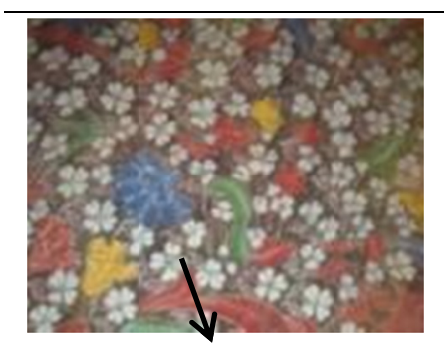

Jasmine flowers

Figure 19. Classical Tanjung Bumi batik with Bhang Melate motif

The name of Tanjung Bumi batik is based on its pattern, isen, and main motif. The patterns are topa, jung drajad, leres, taek melaya, and so on. The isens are ramok akar (root ramok), ramok kerang (scallop ramok), bulu ayam (chicken feather), bhang gadhung (gadhung flower), pi kopi (coffee flower), kobhung, and so on. The main motifs are per keper (butterfly), reng pereng (bamboo), kar jagad (world map), half moon, and so on. In Figure 20 we can see Tanjung Bumi batik with various isens.

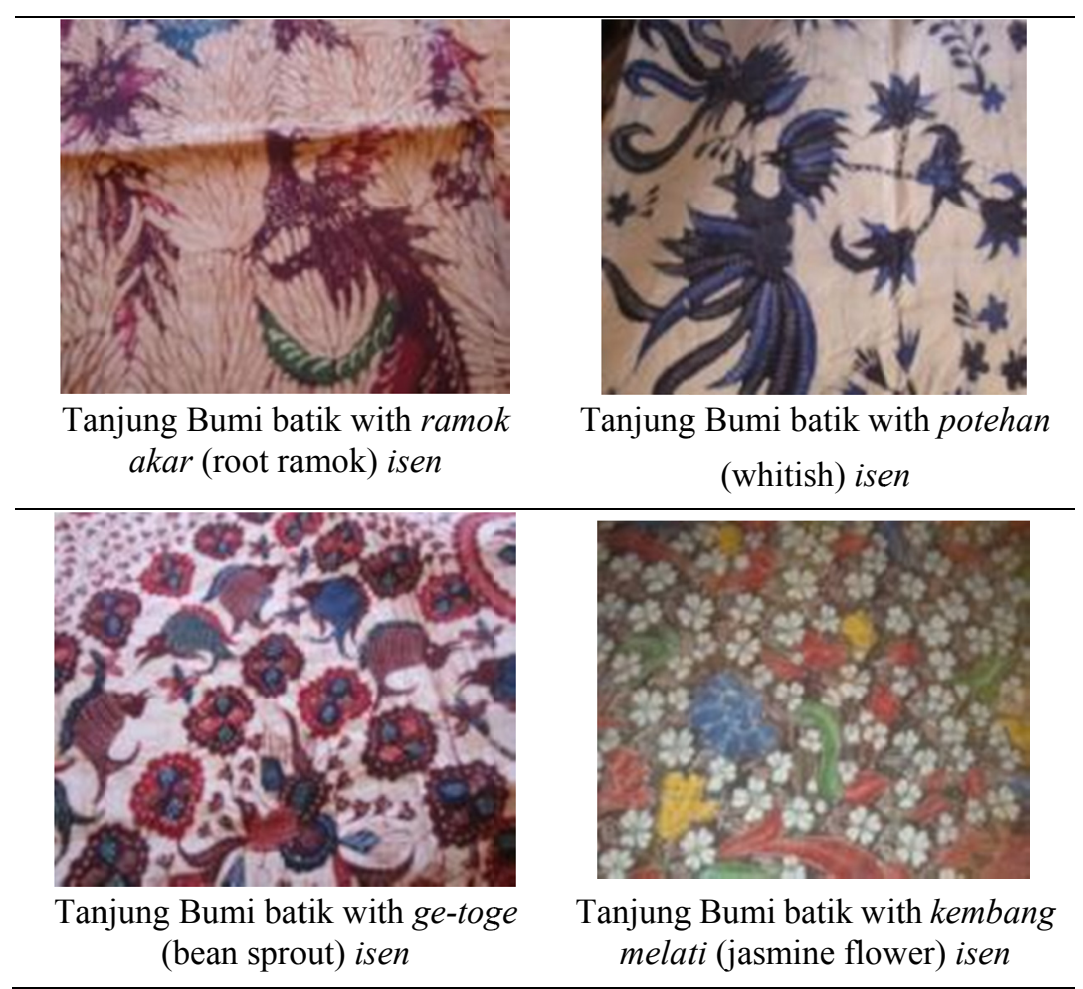

Figure 20. Tanjung Bumi batik with various isens and main motifs

\subsection{The Acculturation of the Chinese Culture in Sumenep Batik}

As in Pamekasan batik and in Tanjung Bumi batik, in Sumenep batik we also find many bird (peacock or phoenix), forest chicken, and butterfly motifs, as can be seen in Figure 21. The customers from Jakarta and 
Surabaya who come from Chinese ethnic like to order batik with white background and flower motif, without isen. The price is around Rp. 150.000,- The coloring is natural color from leaves which are boiled thickly. The bird motif is distinguished from the phoenix motif in the tail. Batik makers in Sumenep are open to foreigners, for example, they will comply willingly when a tourist from China wants to paint his own motif. The coloring process will be done by the Sumenep batik makers. The characteristics of Sumenep batik are principally the same as those of other Madurese batiks. The difference is in coloring, Sumenep batik makers use natural coloring. The blue color is made from indigofera trees, greenish brown color is made from the leaves of jati trees, brown color is made from jaran wood, dark brown color is made from jolawe, while blackish color is made from tingi.

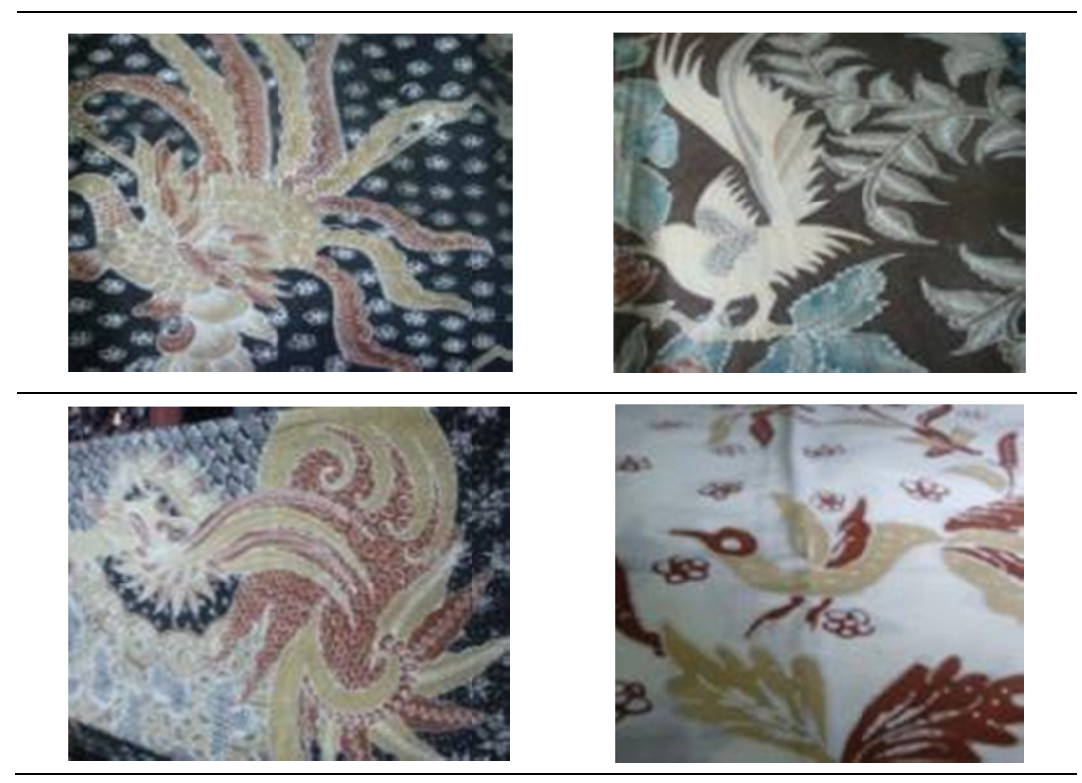

Figure 21. Sumenep batik with various bird motifs

Customers in Sumenep also like abstract contemporary motifs. The abstract motifs in Sumenep are not in the form of garis bangun as in Pamekasan batik, but in the form seen in Figure 22.

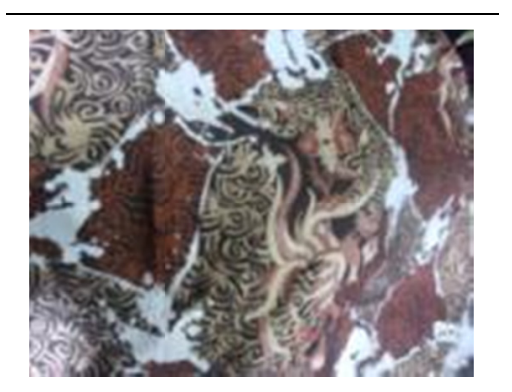

Figure 22. Modern Sumenep batik with abstract motif

Besides abstract motifs, nowadays we also find motifs which tells a local story or tradition, such as karapan sapi (cow race) and mosque, as shown in Figure 23. Wiryoprawiro (1986) says that Sumenep is famous for its cows which are high quality cows. The forest chickens from Kangean Island in the district of Sumenep is also well known among bird lovers in Indonesia. This fact encourage people whose craft is wood carving to make cages for forest chickens (p. 7). It also causes Sumenep batik makers to use karapan sapi (cow racing) and forest chicken motifs. 


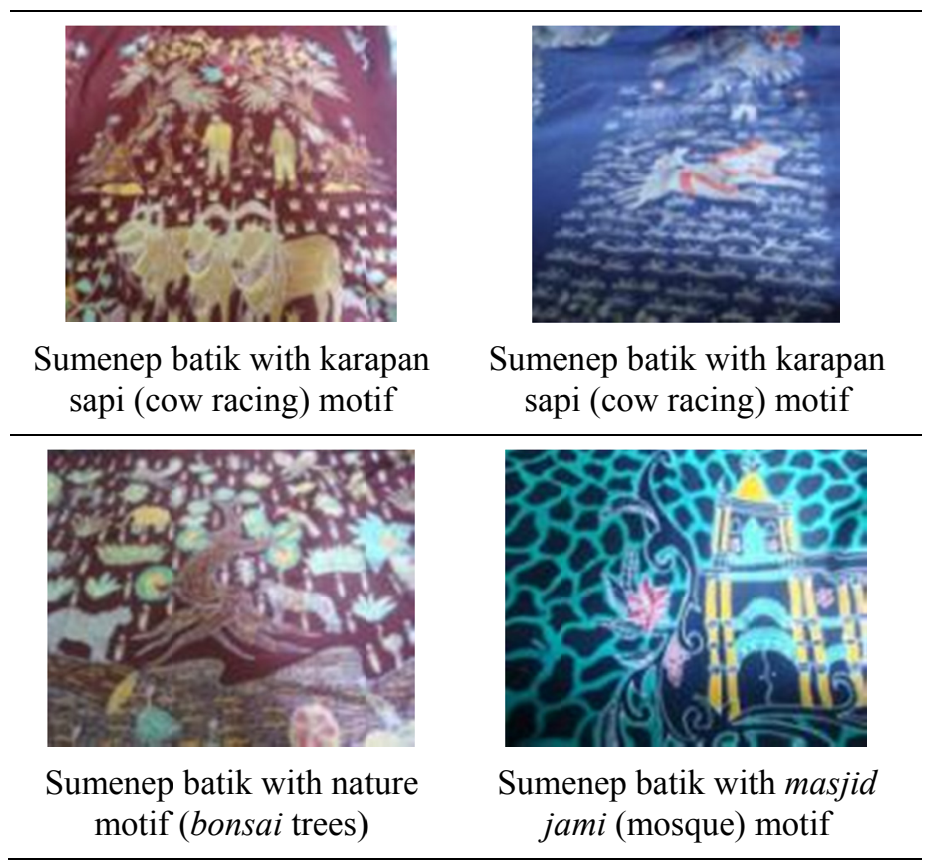

Figure 23. Sumenep batik with motifs of nature and local tradition

In Sumenep batik we can also find dragon and bamboo motifs. This indicates that there has been an acculturation of Chinese culture in Sumenep batik. Figure 24 shows batik with dragon and bamboo motifs. The Madurese call the bamboo motif Reng-pereng.

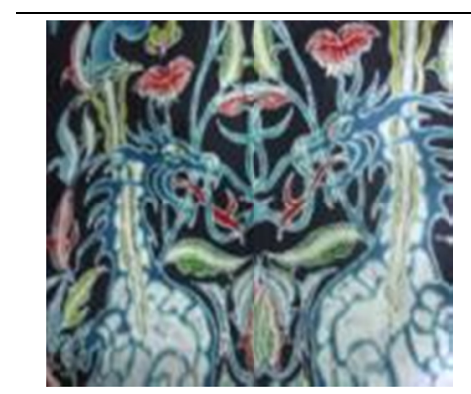

Dragon motif

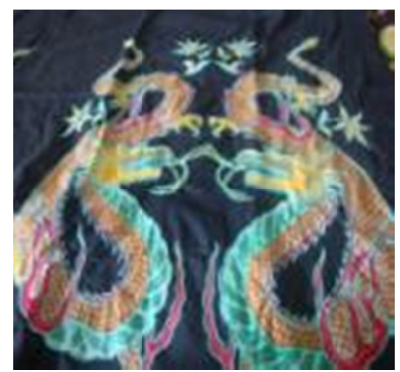

Dragon motif

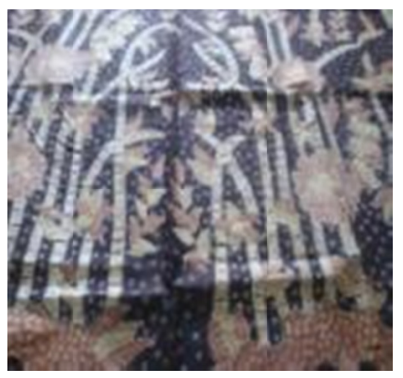

Reng-Pereng (bamboo) motif

Figure 24. Sumenep batik with dragon and reng-pereng (bamboo) motifs

Nowadays, in Sumenep customers can require batik motifs according to their wishes, as the fighting tigers motif (Figure 25).

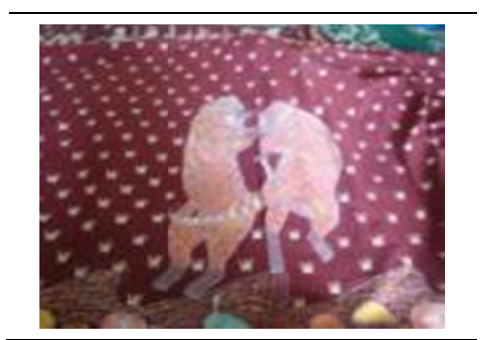

Figure 25. Sumenep batik with fighting tigers motif

Thus, Sumenep batik is open to customer's requirements, and introduces local traditions. There are also butterfly motifs in Sumenep batik, although not as many as in Pamekasan batik and Tanjung Bumi batik. While flower motifs (Figure 26) are greater in number. 


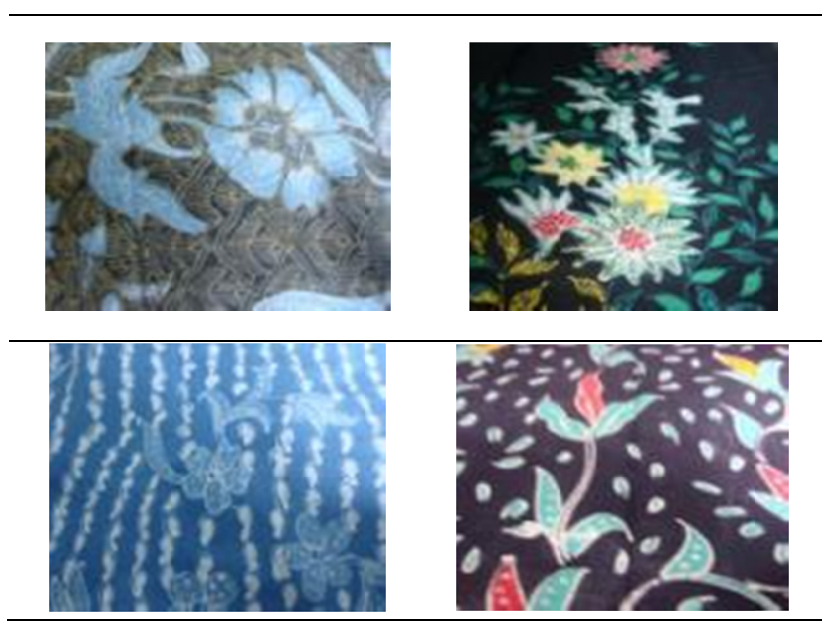

Figure 26. Sumenep batik with flower motifs

Although the motifs of Sumenep batik are more attuned to customer's taste, the classical motif of Sumenep batik is similar to other Madurese batik, namely Sekar Jagad, with different isen and coloring from other Madurese batik. Figure 27 shows the photograph we take of this batik.

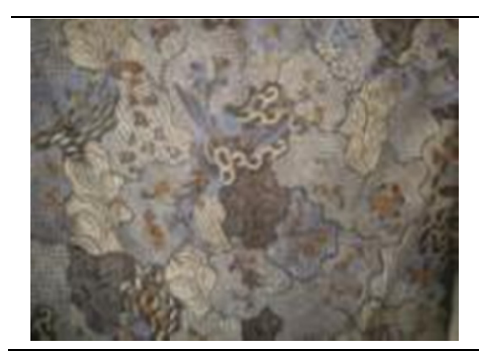

Figure 27. Sumenep batik with Sekar Jaga $d$ motif

The contemporary motifs in Sumenep batik have free design and are usually without isen (Figure 28).

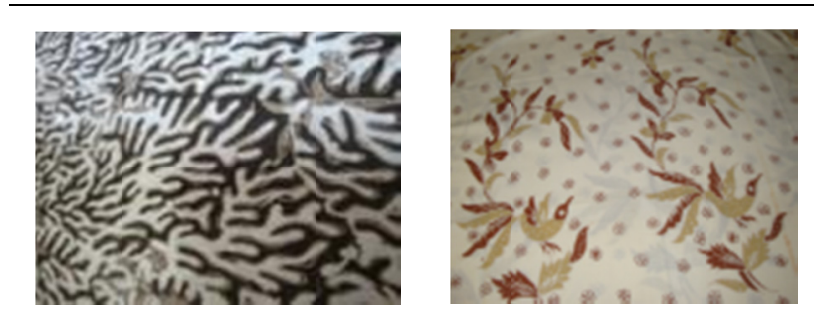

Figure 28. Sumenep batik with contemporary motif

The isen motifs of Sumenep batik are different from the ones in Pamekasan batik and Tanjung Bumi batik. The isen motifs in Sumenep batik are in the form of fish scales, gadung flower, okel (curves), flower of the coffee tree, eler (chain), scallop, grass, and so on. The isen motifs in Sumenep batik is more complying to customer's taste or more contemporary. Figure 29 shows the isen motifs of Sumenep batik. 


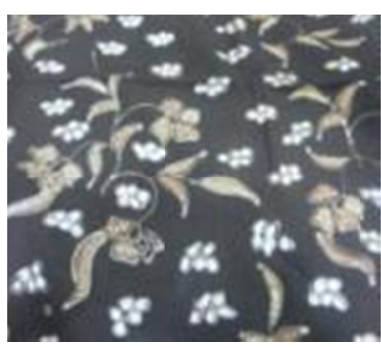

Sumenep batik with contemporary isen motif

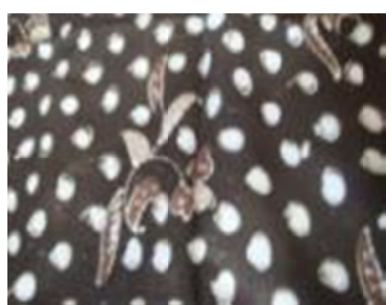

Sumenep batik with contemporary isen motif

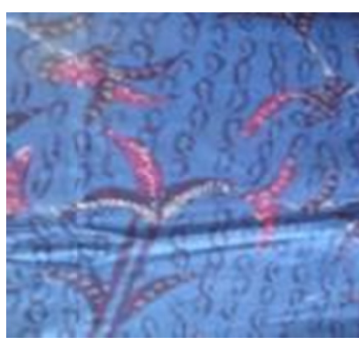

Sumenep batik with okel (curves) isen motif

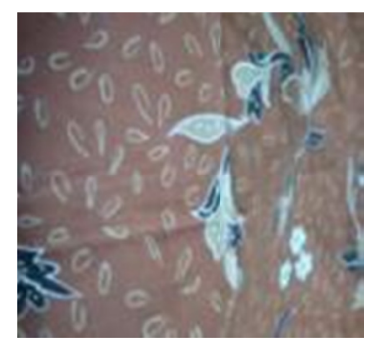

Sumenep batik with contemporary isen motif

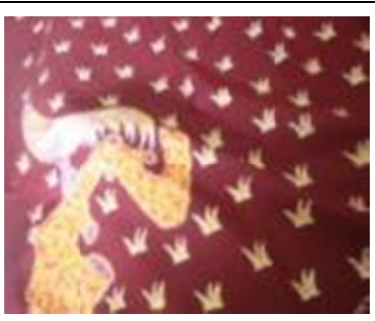

Sumenep batik with contemporary isen motif

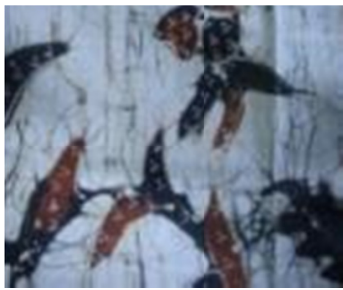

Sumenep batik with remekan isen motif

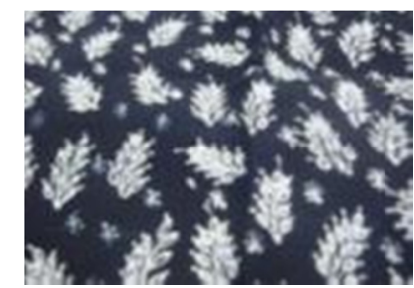

Sumenep batik with flower of the coffee tree isen motif

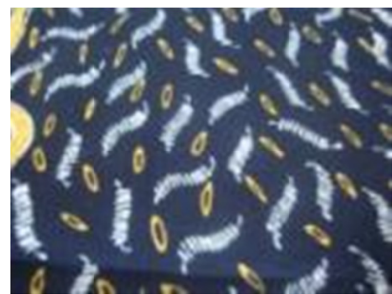

Sumenep batik with gadung flower isen motif

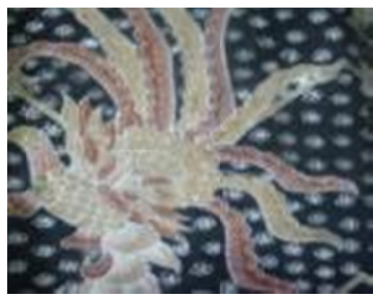

Sumenep batik with giwang isen motif and phoenix main motif

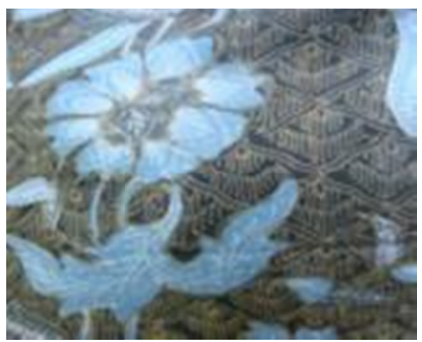

Sumenep batik with fish scales isen motif

Figure 29. Sumenep batik with various isen motifs

Figure 29 shows that the isen motifs of Sumenep batik is more simple and not so dense as the isen motifs of Pamekasan batik and Tanjung Bumi batik. Remekan isen is made in this way: On the night when the color is smeared over the cloth, it is broken so that it will draw thin irregular lines. In coloring, Sumenep batik makers use colors from nature, such as blue from indigofera, black from tingi, brownish from jolawe, greenish from the leaves of jati trees and jaran wood. Hand painted batiks with coloring from nature are usually more expensive than batiks with chemical coloring. Besides, the level of difficulty in painting the motif and in expressing the meaning of a batik also determines the price of the batik. 


\subsection{The Acculturation of the Chinese Culture in Sampang Batik}

The district of Sampang lied around $90 \mathrm{~km}$ from Surabaya, the capital of East Java Province.

(https://id.wikipedia.org/wiki/Kabupaten_Sampang\#Geografis).

The number of batik makers in Sampang is fewer than in Pamekasan, Tanjung Bumi, and Sumenep. Sampang also produces batiks with classical and modern motifs. The batik collector we interview states that Madurese batiks from Pamekasan, Tanjung Bumi, Sumenep, and Sampang are a little different from one another, which can not be easily distinguished by new batik lovers. Pamekasan batiks have been impregnated by outside elements so that they are more various and colorful. Tanjung Bumi batiks still retain their rules and coloring. Sumenep batiks which are produced in a coastal region have also been impregnated by outside elements so that the rules are not so strictly obeyed. Sampang batiks do not experience much innovation so they are more original but on the other side, they are too monotonous.

The acculturation in Sampang batik can also be seen in its motifs. We find that there is an acculturation of the Chinese culture with the Madurese culture in Sampang batik in the form of phoenix motifs. The photographs are given in Figure 30.
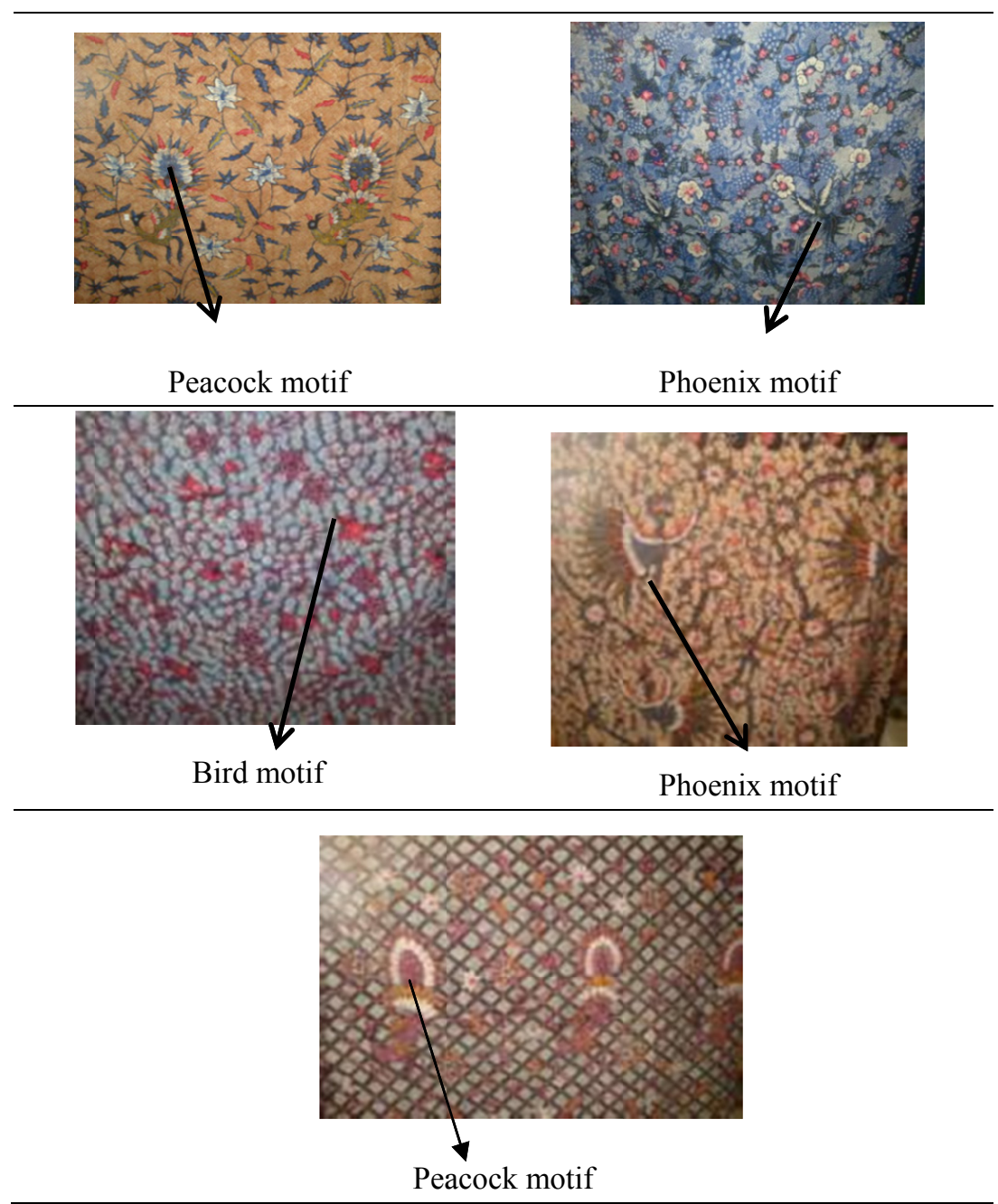

Figure 30. Sampang classical batik with various bird motifs

Besides bird motifs there are also Car Cena motif which is taken from pacar cina flowers which are commonly used to paint ladies' nails. In Figure 31 we can see the photograph of Sampang batik with Car Cena motif. 


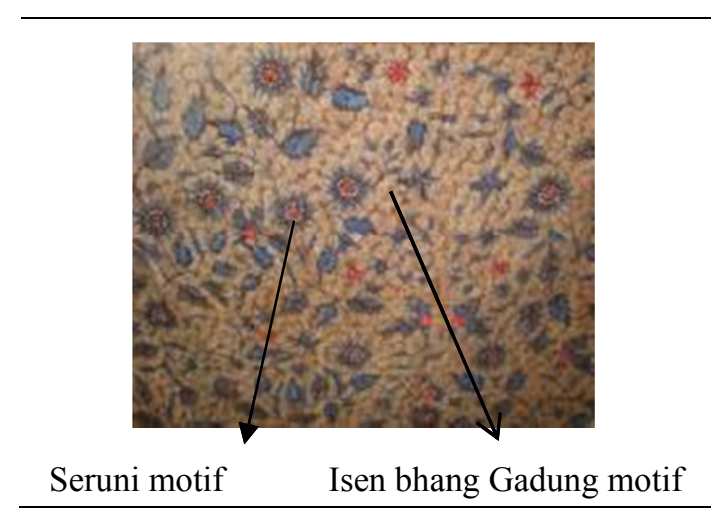

Figure 31. Sampang batik with sruni (crysanthemum flower) motif and kembang gadung (gadung flower) isen

The characteristics of the isen in Sampang batik lie on the forms like kembang gadung (gadung flower), kembang jeruk (orange flower), rawan (straight and curving lines). Sampang batik isens are dominated by kembang gadung (gadung flower) and kembang jeruk (orange flower) isens (Figure 32).

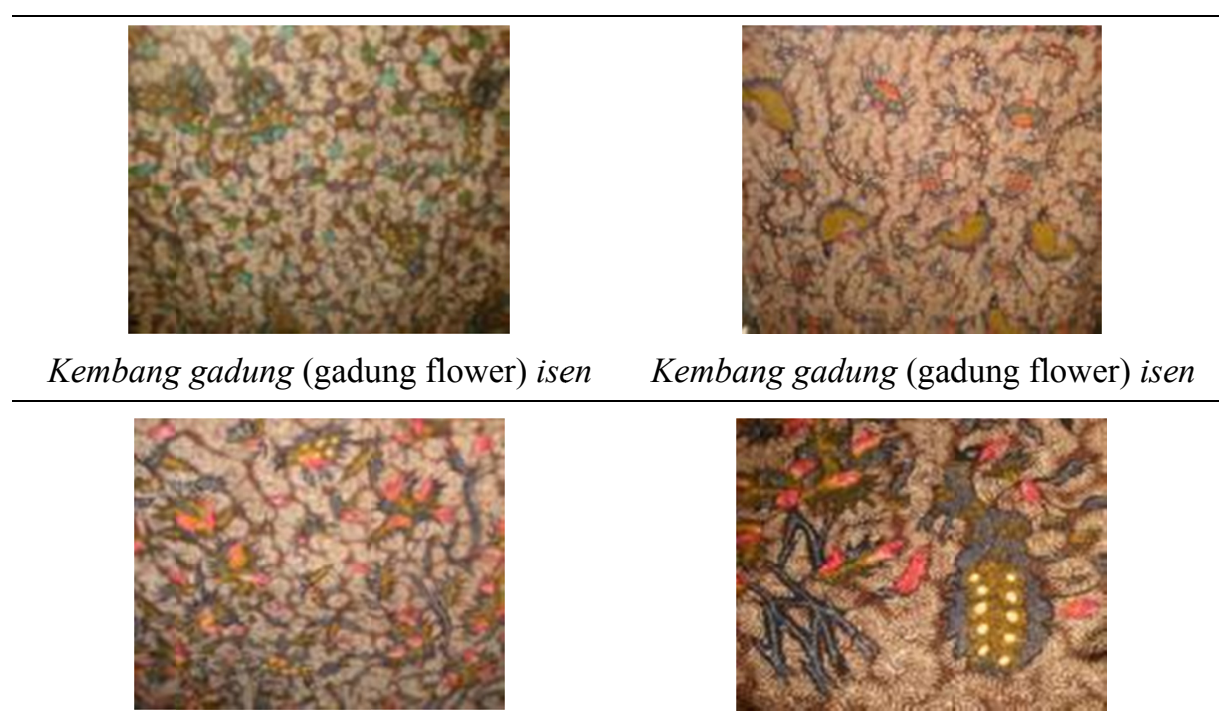

Kembang gadung (gadung flower) isen Kembang gadung (gadung flower) isen

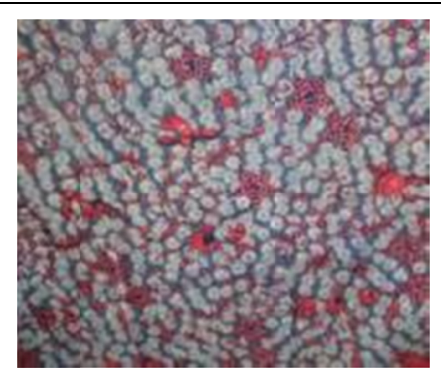

Kembang jeruk (orange flower) isen

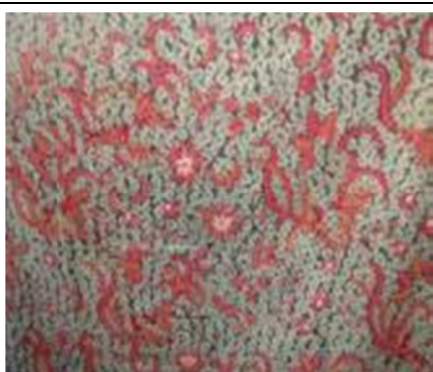

Kembang jeruk (orange flower) isen

Figure 32. Sampang batik with kembang gadung (gadung flower) and kembang jeruk (orange flower) isens

Kembang gadung (gadung flower) isen of Sampang batik is different from those of Sumenep batik or Tanjung Bumi batik or Pamekasan batik, because in Sampang batik the isen is painted in circles while in the other batiks the isen is painted in straight lines. We can see the examples of these isens in Figure 33. 


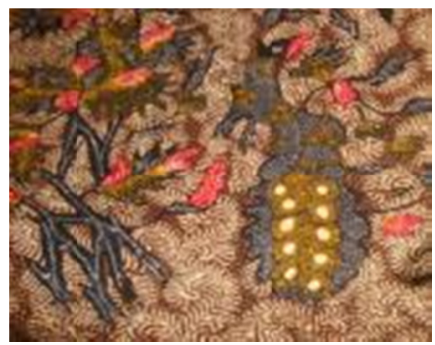

Kembang gadung (gadung flower) isen

in Sampang batik

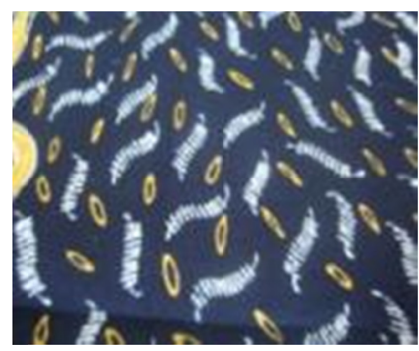

Kembang gadung (gadung flower) isen

in Sumenep batik

Figure 33. The difference between kembang gadung (gadung flower) isen of Sampang batik and modern Sumenep batik

The modern Sampang batik has no isen, only main motif in the form of flowers or bouquets which are called buketan on black background (Figure 34).

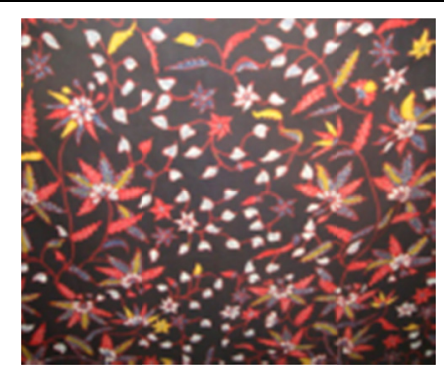

Figure 34. Sampang batik with flower motif without isen

In Sampang we also find classical batik motifs such as bamboo, sekar jagad, and per-keper (butterfly) motifs. The philosophical meaning of the bamboo tree is, as has been given previously, to advice the Madurese to live courageously and never give up. The philosophical meaning of sekar jagad has also been explained previously, which is to symbolize the joy of a young couple. While per-keper is the Madurese term for kupu-kupu (butterfly) which symbolizes the true love between the bridegroom and the bride for as long as they live. Per-keper motif in Madurese batik reminds us of the Chinese legend which tells of the love between a pair of lovers titled Sam Pek Ing Tai or in bin yin spelling Liángshānbó yǔ Zhùyingtái 梁山伯与祝英台. This proves that there has been an acculturation process in the motifs of Sampang batik. The photographs can be seen in Figure 35.

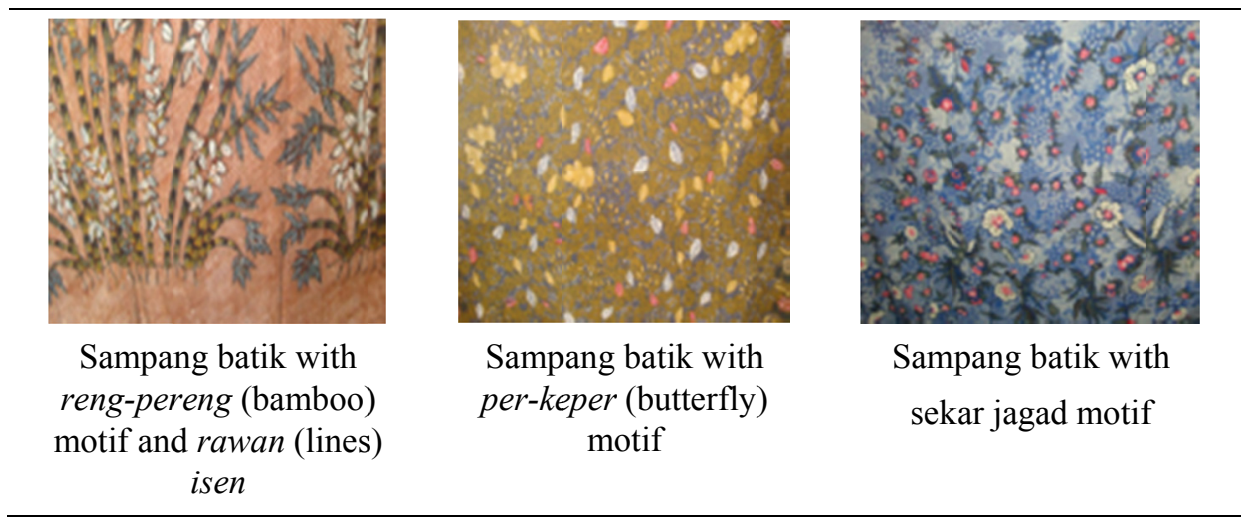

Figure 35. Batik Sampang with bamboo, sekar jagad, and per-keper (butterfly) motifs

Other motifs are also found in Sampang batik, among others sea creature motifs like crab and shrimp motifs. We can also see bird motif in Sampang batik. This shows that the Madurese really like bird motif. In Figure 36 we can see the photographs of this batik. 


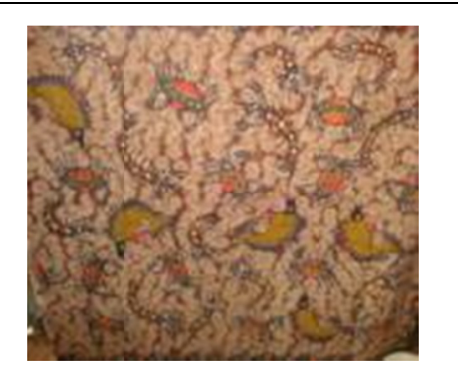

Figure 36. Sampang batik with sea creatures motif

In Sampang batik we also see an acculturation of Chinese culture in the form of phoenix motif accompanied with various local isens. The photograph of this batik is given in Figure 37. The bird in this batik is not Indonesian bird, the beauty of its tail symbolizes the beauty and elegance of a girl in the Chinese culture. While the isen is kembang jeruk (orange flower) isen.

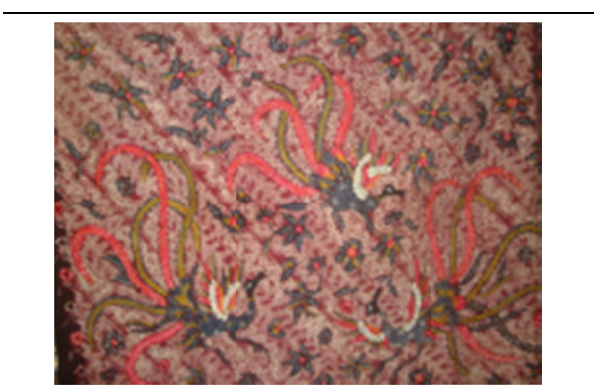

Figure 37. The acculturation of Chinese culture in Sampang batik in the form of phoenix combined with local isen

Besides the acculturation in the form of phoenix combined with local isen, in Sampang batik we can also find the acculturation in the form of dragon with Chinese letters on the background of local flower isen. (Figure 38)

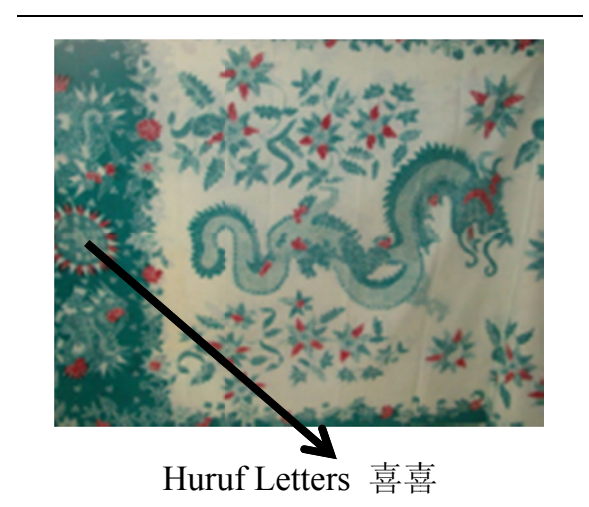

Figure 38. The acculturation of Chinese culture in Sampang batik in the form of dragon with Chinese letters 喜喜 on the background of local flowers inside a sling cloth

The batik makers in Sampang whom we interview tell us that besides the Figure of dragon there is also the Chinese letters 喜喜, read shuāngx̌̆, which means double happiness. These letters are usually pasted on doors and windows on the marriage day, which symbolizes abundant happiness. Besides the motifs that have been discussed above, there are also other motifs from other regions of Madura such as fan, jung derajad, and so on (Figure 39). 


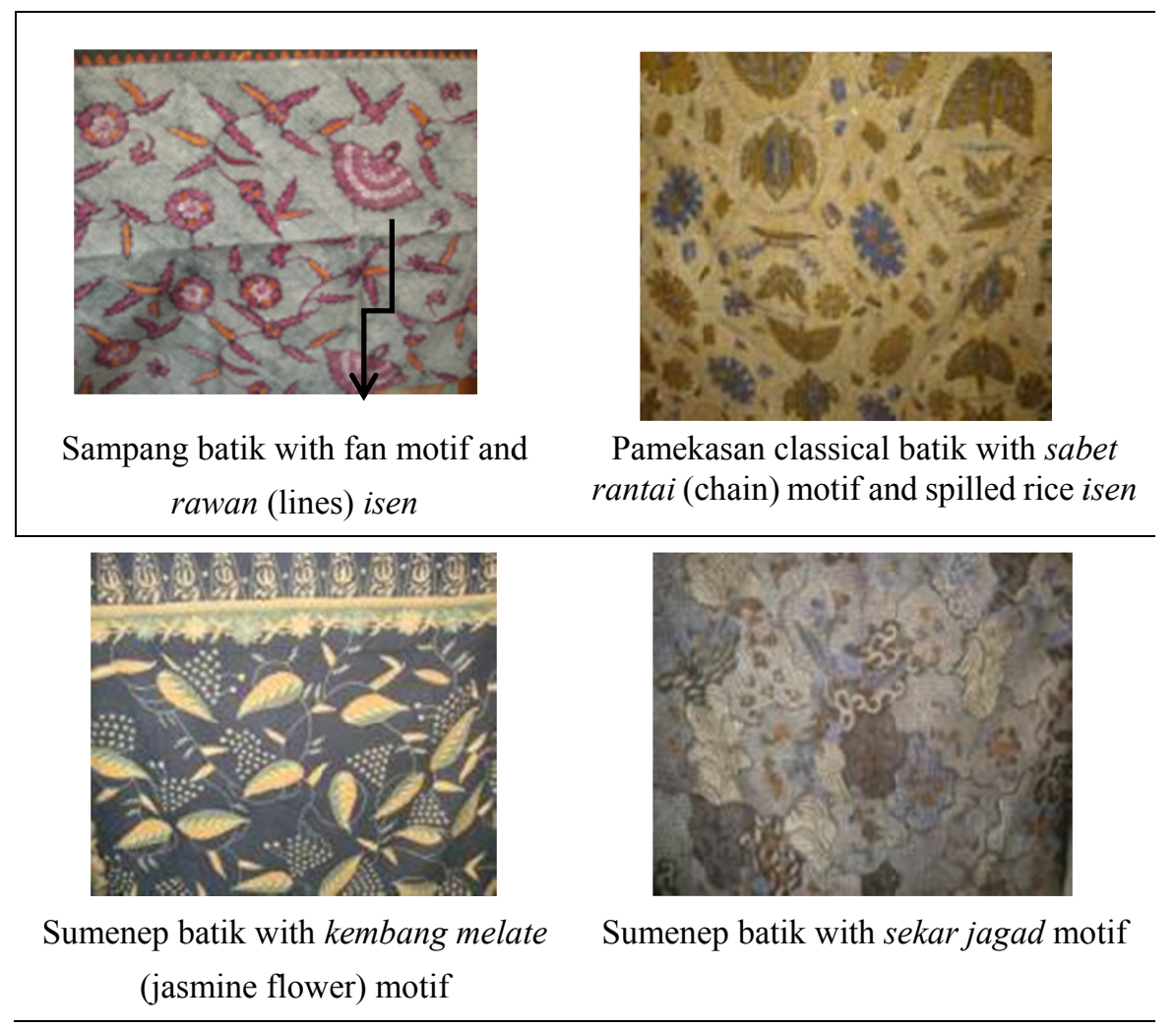

Figure 39. The various motifs of Madurese batik

We can still detect the philosophical meanings of some of Sampang batiks. Madurese classical batiks still have philosophical meanings, while modern Madurese batiks do not have names nor philosophical meaning. There is also no rule in painting modern motifs, batik makers can paint the modern motifs freely according to customer's wish or his own creativity.

Concerning the price of batik, not only with Madurese batik but with all Indonesian batik, the price is determined by the motif and the coloring process, the coloring substance used for coloring and how many times the coloring process is carried out. Coloring substance from nature is usually more expensive than chemical ones. The price is also influenced by the technique of making the batik, if the cloth is painted on both sides (inside and outside), the price will be more expensive, because the process takes a longer time, which can take years. Batik makers very rarely do this. So the price of this batik can reach around Rp. 2.000.000. Other factors which influence price are the isen and the number of isens painted on the batik, and the quality of the cloth.

\subsection{The Determinant Factors in the Acculturation of the Symbols of the Chinese Culture in the Motif of Madurese Batik}

From observation among and interviews with the research subjects as research informants, from Pamekasan, Tanjung Bumi, Sumenep, and Sampang, we find that they paint their batik without thinking of its philosophy. The creation of the motifs spontaneously emerge while they are painting the motif. Thus, the determinant factor in the acculturation of the symbols between the Chinese culture and the Madurese culture lies in the relationship between customer and batik maker. If there are many customers from Indonesians of Chinese origin, they prefer motifs which contain Chinese culture, such as the Figure of dragon, phoenix, and bright colors. This causes acculturation in batik motif, namely the main motif is from Chinese culture while the background isen is from local Madurese culture. Because they do not care much about the philosophy of the batik, contemporary batiks do not have certain rules and their main motifs are more free. On the other hand, in classical motifs, the modern Madurese batik makers only need to copy the motifs which have been inherited from their ancestors, which have philosopical meanings. The classical motifs which have philosophical meanings are among others sekar jagad motif, sabet rantai motif, reng-pereng motif, melate seto'or motif, per-keper motif, and tong-centong motif.

According to Wiryoprawiro (1986), the cause of the acculturation was among others, since year 1624 during the reign of King Amangkurat II, Sumenep has been influenced by Dutch culture. When the Sumenep palace was built, it was impregnated by foreign culture. This was caused by Panembahan Sumo and his Chinese architect 
whose name was Lauw Pia Ngo. Since then wood carvings with Chinese characteristics flourished in Sumenep. (pp. 158-159). Thus the acculturation process has taken place since a long time ago, therefore we find many motifs of Madurese batik with Chinese symbols such as phoenix, butterfly, bamboo, heron, fish. Koentjaraningrat also states that acculturation in Indonesian culture has taken place since ancient times (1990, p. 248-249). The acculturation of European culture in Indonesia has occured since the entrance of VOC to Indonesia. Thus, the acculturation, both of European culture and Chinese culture has occured naturally since acient time up to the present time in the Madurese community.

The acculturation of the Chinese culture in Madurese batik occurs naturally because both the Madurese and the Chinese have the same preferences, both like the Figure of bird, butterfly, and bamboo. The Madurese and Indonesians of Chinese origin consider a pair of butterflies as the symbol of a pair of lovers. The acculturation of the phoenix motif is supported by the fact that the Madurese also like the Figure of birds, that is why many of their batik motifs have the Figure of birds. When the bird's tail is not spread, it becomes peacock motif, when the bird's tail spreads beautifully, it becomes phoenix motif. This acculturation process is also strengthened by the openness of Madurese batik makers in developing the motifs of their batiks. They allow customers, including foreign ones, to create their own motifs, or to order motifs according to their own wishes, and even to paint the motifs themselves, and after that the batik makers will do the coloring process.

\section{Conclusions}

After observing the motifs of Madurese batik from the towns of Pamekasan, Tanjung Bumi, Sumenep, and Sampang, and analyzing the information obtained from the interviews with batik makers and batik collectors, we conclude that there is much acculturation of the Chinese culture in the motifs of Madurese batik. This acculturation process has occured since ancient times and does not only touch batik making, but also influences other fields including architecture and building ornaments. The batik motifs which have experienced acculturation are mostly plant and animal motifs. The plant motifs which are adopted into the motif of Madurese batik among others is the bamboo tree, because both the Madurese and the Chinese believe that the bamboo tree can live in any season, thus giving us example to do likewise. The animal motifs which have been adopted are among others butterfly, phoenix, fish, and heron.

Concerning the animal motifs adopted from the Chinese culture, both the Chinese and the Madurese consider that these animals symbolize positive things. The Chinese and the Madurese believe that per-keper or a pair of butterflies motif symbolizes the true love between a pair of lovers. The Chinese consider the phoenix motif as the symbol of a girl's beauty and elegance, while the Madurese like birds, especially in Sumenep which is famous for its forest chickens. Thus we find the phoenix in the motif of Madurese batik. The fish motif in the Chinese community symbolizes abundant food, while the Madurese like the Figure of fish because many Madurese husbands work as fishermen. The heron with one leg uplifted is taken as such by the Madurese from the Chinese motif.

The panji (swastika) isen motif which symbolizes a balanced life also indicates an acculturation of Chinese culture in Madurese batik.

\section{Acknowledgements}

We would like to express our gratitude to Direktorat Jenderal Pendidikan Tinggi (Directorate General of Higher Education in Indonesia) for the moral and financial support given to us so that we can perform this study smoothly and sucessfully, and can publish it in an international journal.

\section{References}

Batik Market. (2015). Retrieved from http://www.batikmarkets.com/cara_membuat_batik.php

Chinese Encyclopedia Online. Retrieved from http://ap6.pccu.edu.tw/Encyclopedia_media/main-h.asp?id=5461

Fadilah, N. (2010). Karakteristik Batik Madura antara Kabupaten Bangkalan danPamekasan (Unpublished article). Strata 1Program State University Malang.

Gǔ, J. Sh. (2014). Zhōngguō làrán yìshù de lìshǐ (I). Retrieved from http://www.laomiaoren.com/bbs/upload/ article-7-2.html

Hán, J, T. (2002). Zhōnghuá wénhuà. Běijīng: Běijīng yǔyán dàxué chūbănshè.

Karsono, O. M. F. (2014). Chinese Language an Identity Viewed by the Younger Chinese Ethnics in Indonesia. Journal of Language and Literature, 5(2), 5-10. http://dx.doi.org/10.7813/j11.2014/5-2/1

Karsono, O. M. F. (2015). Batik Madura dan Budaya Tionghoa. Surabaya: Perwira Media Nusantara. Kamus 
Besar Bahasa Indonesia. Retrieved from http://kbbi.web.id/lengkap

Karsono, O. M. F., \& Suprapto, W. (2014). The Downfall of Chinese Family Businesses in East Java, Indonesia. International Journal of Academic Research: Part B, 6(6), 298-304. http://dx.doi.org/10.7813/2075-4124. 2014/6-6/B.46

Koentjaraningrat. (1990). Pengantar Ilmu Antropologi. Jakarta: Rineka Cipta.

Kong, Y. Zh. (1999). Silang Budaya Tiongkok Indonesia. Jakarta: PT Bhuana Ilmu Populer.

Minister of Tourism and Creative Economy Republic of Indonesia. (2009). Indonesian Batik from Tradition to Global Trend. Jakarta: Minister of Tourism and Creative Economy Republic of Indonesia.

Ong, H. T. (1993). Chinese Animal Simbolisms. Malaysia: Pelanduk Publications.

Prasetyo, S. (2014). Lambang Swastika Tak Selalu Gelap. Jurnal Bumi. Retrieved from https://jurnalbumi. wordpress.com/2014/11/03/lambang-swastika-tak- selalu-gelap/

Samsi, S. S. (2011). Techniques, Motifs \& Patterns Batik Yogya \& Solo. Solo:YayasanTitian Masa Depan.

Setyorini, Ch. T., Pinasti, M., \& Rokhayati, H. (2013). Strengthening the Internal Factors of Batik Cluster SMEs in Indonesia: A Case of Six Districts in South - Central Java. International Journal of Business, Humanities and Technology, 3(1), 22.

Sunaryo, A. (2009). Ornamen Nusantara. Semarang, Dahara Prize.

The Overseas Chinese Affairs Office of the State Council. (2007). Zhōngguó wénhuà chángshí. Běijīng: Wàiyǔ jiàoxué yu yánjiū chūbănshè.

Tulistyantoro, L. (2009). The Acculturation of Foreign Cultures on Ranjang Madura. Paper presented at the seminar of Maranatha University. Bandung.

Wáng, E. L. (2012). Tègăo: Màntán Hóngsè Wénhuà. Retrieved from http://www.crt.com.cn/news2007/news/ 2012HSWH/12111230483I5787G6DDCFIB4A3A5E.html

Williams, C. A. S. (1993). Chinese Symbolism and Art Motifs (3rd ed.). Tokyo: Charles Turtle Company.

Wiryoprawiro, Z. M. (1986). Arsitektur Tradisional Madura Sumenep. Surabaya, Laboratorium Arsitektur Tradisional FTSP ITS.

Wolody, Sh., \& Chain, Ng. W. (2004). The Book of Batik Fiona Kerlogue. Singapore: Archipelago Press.

Yáo, M. Y. (2013). Zhōngguó shànzi. Zhéxuéxì shuòbó xuéshù shālóng zǒng dì 58 qī jiăngzuò. Retrieved from http://hsslab.xmulib.org/?p=4297

\section{Copyrights}

Copyright for this article is retained by the author(s), with first publication rights granted to the journal.

This is an open-access article distributed under the terms and conditions of the Creative Commons Attribution license (http://creativecommons.org/licenses/by/3.0/). 